\title{
The Effects of Race and Space on City-County Consolidation: The Albany-Dougherty Georgia Experience
}

\author{
Kwame Boakye Dankwa, Timothy Sweet-Holp \\ Department Political Science, Albany State University, Albany, USA \\ Email: kwame.dankwa@asurams.edu, timothy.sweet-holp@asurams.edu
}

Received 19 July 2015; accepted 7 September 2015; published 10 September 2015

Copyright (C) 2015 by authors and Scientific Research Publishing Inc.

This work is licensed under the Creative Commons Attribution International License (CC BY). http://creativecommons.org/licenses/by/4.0/

\section{c) (i) Open Access}

\begin{abstract}
In this paper the authors summarize the history of government consolidation successes and failures in Georgia, discuss regionalism and functional consolidation, and address social-structural barriers to unified government. The paper focuses on the 60 -year consolidation movement and current unification efforts in Albany-Dougherty County, GA. Since knowing citizen perceptions is vital in understanding the resistance to consolidation, the paper concludes with findings from a 2012 Exit Poll in Dougherty County, GA.
\end{abstract}

\section{Keywords}

Consolidation, Regionalism, Unified Government, Georgia, City, County, Race, Space

\section{Introduction}

In this paper, we look at a brief history of consolidated government in Georgia and, specifically, consolidation efforts in Albany City and Dougherty County. Included are findings from an Election Day (2012) exit poll measuring Dougherty County (incorporated and unincorporated) voters' opinions on the possible merger of city and county governments in Dougherty, Georgia.

Consolidation is defined as the merging of a county government with one or more municipal governments in a metropolitan area to create a single and unified governmental entity. A consolidated City-County or metropolitan municipality is also known as regional municipality. In American local government parlance, this means a city and county that has been merged into one jurisdiction. Consolidated city-counties may also be called metropolitan governments and metropolitan counties (Carr, 2004).

Proponents of consolidation believe that a consolidated government will bring about efficiency by doing away 
with governmental duplication, and unnecessary competition among local governments, patronage, and corruption. It is further argued that consolidating two or more local governments can improve efficiency by achieving economies of scale. By improved efficiency, the logical assumption is that consolidated local governments can ultimately lower property taxes and reverse out migration patterns to nearby suburbs (Leland \& Johnson, 2004: p. 25). Advocates further believe that consolidation improves representation, increases responsiveness, and results in greater accountability from local government officials (Johnson, 2004: p. 158).

The agitation for governmental consolidation is not new in America. While the desire to be governed by one's local government dates back to America's founding, the invention of quicker modes of transportation makes regional governments attractive. By the 1860s and 1870s, citizens welcomed some forms of annexation because big cities could offer water, sewer, and other services (O'Toole, 2005: p. 1). A coalition of scholars of public administration, chambers of commerce, and business elites emerged in the late nineteenth and early twentieth centuries to champion municipal reforms geared towards administrative efficiency and to break the influence of politics on local decisions. These "progressives" actively pursued City-County consolidation as a means to reduce costs and promote efficiency in services by achieving economies of scale and increase production efficiency.

Attacking the corruption of political machines in several cities, the progressives intensified their efforts to introduce institutional changes that would consolidate governmental authority between the 1930s and 1950s (Feiock, 2005: p. 40). After losing its momentum in the 1980s and much of the 1990s, interest in City-County consolidation has made a great resurgence into American politics under the direction of the "New Regionalism" movement. While only twenty-five referenda were conducted in the entire decade of the 1980s, after the successful City-County consolidation of Wyandotte County with Kansas City, Kansas in 1997, more than a dozen communities had either submitted consolidation referenda to voters or conducted consolidation studies preparatory to such a referendum by 2002. Three such communities have voted to consolidate their governments. In 1998 the consolidated city and county government of Broomfield, Colorado was approved, Louisville and Jefferson County, Kentucky were consolidated in 2000, and the town of Hartsville was consolidated with Trousdale County, Tennessee, in 2002 (Carr, 2005: pp. 4-5).

\section{Literature Review}

\subsection{Background and History}

There have been as many as twenty-eight (28) attempts at City-County consolidation throughout Georgia in the last four decades. This could be attributed - in part—to Georgia's rather large number of counties. For a state that ranks 21st in land area, Georgia's 159 counties are second only to the State of Texas. Most of these counties are rural by classification, with few or no incorporated municipalities other than the county seat. While 45 counties have populations under 10,000, thirty-six counties are less than 250 square miles including Clarke County, the smallest in Georgia with 121 square miles. This reality of too many local governments and too little coordination has resulted in policy makers at the state and local levels of government working to find solutions to make local governments more viable. One option is consolidated government.

\subsection{Consolidation in the State of Georgia}

Of the consolidating campaigns that reached the referendum stage, citizens rejected the following: consolidation failed in Rockdale County and the City of Conyers in 1989, Bibb County and the City of Macon was rejected for the last time in 1976, while that of Glynn County and the City of Brunswick was defeated in 1987 (Johnson \& Carr, 2004: p. 248).

Out of the thirty-four (34) consolidation referenda held throughout Georgia, only seven (7) have been ratified. Muscogee County consolidated with the City of Columbus in 1970, Clarke County consolidated with the City of Athens in 1990, and Richmond County sealed a consolidation pact with City of Augusta in 1995 (National Association of Counties, 2014). Table 1 displays ratification attempts in Georgia and their success or failure.

Despite the low success rate, consolidation fever in Georgia has not abated. Although in the last thirty years, no other local efforts towards consolidation had led to a successful referendum until 2003 when four (4) more attempts were approved by voters. In 2003 Chattahoochee County and Cusseta City merged, while Quitman County and Georgetown City were successful in 2006. They were joined by Webster County and Preston City, 
Table 1. Ratification attempts In GA.

\begin{tabular}{|c|c|c|c|}
\hline Year & City & County & $\mathrm{P} / \mathrm{F}$ \\
\hline 1933 & Macon & Bibb & Fail $^{*}$ \\
\hline 1954 & Albany & Dougherty & Fail \\
\hline 1956 & Albany & Dougherty & Fail \\
\hline 1960 & Macon & Bibb & Fail \\
\hline 1962 & Columbus & Muscogee & Fail \\
\hline 1969 & Athens & Clarke & Fail \\
\hline 1969 & Brunswick & Glynn & Fail \\
\hline 1970 & Columbus & Muscogee & Pass \\
\hline 1971 & Augusta & Richmond & Fail \\
\hline 1972 & Athens & Clarke & Fail \\
\hline 1972 & Macon & Bibb & Fail \\
\hline 1973 & Savannah & Chatham & Fail \\
\hline 1974 & Augusta & Richmond & Fail \\
\hline 1976 & Augusta & Richmond & Fail \\
\hline 1976 & Macon & Bibb & Fail \\
\hline 1982 & Athens & Clarke & Fail \\
\hline 1984 & Tifton & Tift & Fail \\
\hline 1986 & Lakeland & Lanier & Fail \\
\hline 1987 & Brunswick & Glynn & Fail \\
\hline 1988 & Augusta & Richmond & Overturned \\
\hline 1989 & Conyers & Rockdale & Fail \\
\hline 1990 & Athens & Clarke & Pass \\
\hline 1991 & Griffin & Spalding & Fail \\
\hline 1994 & Douglasville & Douglas & Fail \\
\hline 1994 & Metter & Candler & Fail \\
\hline 1995 & Augusta & Richmond & Pass \\
\hline 1997 & Griffin & Spaulding & Fail \\
\hline 1998 & Waycross & Ware & Fail \\
\hline 2000 & Hawkinsville & Pulaski & Fail \\
\hline 2001 & Gainesville & Hall & Fail \\
\hline 2003 & Cusseta City & Chattahoochee & Pass \\
\hline 2006 & Georgetown & Quitman & Pass \\
\hline 2008 & Preston & Webster & Pass \\
\hline 2008 & Statenville & Echols & Pass \\
\hline
\end{tabular}

*The Macon-Bibb County consolidation effort was finally ratified by voters on July 30, 2012.

and Echols County and Statenville City in 2008. Agitation for more consolidation in Georgia could be justified by the sheer number of rural Georgia counties that are unincorporated. Many of Georgia's 159 counties outside metropolitan Atlanta have few municipalities other than the county seat, 45 counties have populations under 10,000, while 36 counties are less than 250 square miles (Fleischmann, 2000).

Dougherty County, together with its city, Albany, could be the eighth such county-city consolidation in Georgia if current efforts towards that move materialize. The impetus for consolidation of county/city governments in Albany-Dougherty was rekindled by the 1997 Georgia General Assembly Legislation (HB489). This landmark legislation sought to provide a flexible framework for local governments in each county to develop a service de- 
livery system that is both efficient and responsive to citizens in their county. The ultimate intent is to "minimize inefficiencies resulting from duplication of services and competition between local governments and to provide a mechanism to resolve disputes over local government service delivery, funding equity, and land use" (Georgia House of Representatives, 1998).

\subsection{Regionalism}

The arguments for and against consolidating county and city governments as a means to ensure more effective and efficient mechanism to deliver goods and services in a geographical area put consolidation under the purview of regionalism as an economic development paradigm. Regionalism, incidentally, evokes powerful reactions when applied at both inter-state and intra-state levels.

At the intra-state level, regionalism entails traditional prescriptions for metropolitan areas such as centralization and consolidation of local governments and functions as well as decentralized approaches to governance (Savitch \& Vogel, 2000). Advocates of intra-state level regionalism contend that because problems and resources needs extend well beyond individual community boundaries, approaches to solving those problems and addressing those resource deficiencies should be regional in scope (Koven \& Lyons, 2010: p. 274).

Regional cooperation among cities, boroughs, and counties in the United States is hardly a new idea. Since the union of Manhattan, Brooklyn, Queens, Staten Island, and the Bronx made New York a regional metropolis in 1898, various perspectives of regionalism has occupied the attention of academics (Katz, 2000).

Under the old regionalism model, urban scholars favor the process of consolidating cities and their suburbs into general-purpose metropolitan governments. The rationale here is that the way to capture the suburban tax base is through aggressive annexation. Another version of old regionalism does not just target the suburban tax base by annexation. Rather, the consolidated region functions as a single zone for trade, commerce, and communication (Koven \& Lyons, 2010: p. 49).

Proponents of new regionalism, in contrast, argue against a centralized control of local governments, per se. They rather call for voluntary local measures and inter-local cooperation among a region's local governments, questioning the political feasibility of replacing towns with a regional authority. Advocates for new regionalism point to the fact that the, usually affluent suburban residents, are almost always unwilling to dismantle their local system of government to bail out their urban neighbors.

\subsection{Alternatives and Degrees of Consolidation}

As mentioned above, City-County consolidation continues to be the preferred choice of public officials, academics, and government administrators in making local governments more efficient and effective. However, considering the inherent difficulties associated with consolidation, academics, since 1979 have been exploring other less radical changes to consolidation that could be more politically feasible. Among such alternatives are municipal annexation, contracting for services through inter-local agreements with other governments, and the creation of special district governments. Indeed, there is empirical evidence showing that these alternatives to consolidation may provide much of the same benefits without the attendant problems associated with a unified metropolitan government (Carr, 2004: p. 7; Brierly, 2004: pp. 87-112).

Consolidation normally entails the merging of two or more governments into one. The term can also apply to a partial merging of services or departments of two or more governments, known as functional consolidation. This concept, as a strategy, has the potential benefit of overcoming some of the major economic and social dislocations that take place with the physical merger of two or more governments. Apart from retaining the basic governmental structures already existing, functional consolidation does not involve a change in the boundaries for the areas where property tax revenues will be drawn. The retention of previous boundaries can offset citizen discontent over possible property tax increase in cases where there is a large disparity between the property wealth of one jurisdiction over others.

Unlike a full consolidated government, which almost precludes any return to the status quo, a functional consolidation is temporary in nature and can be abrogated by a newly elected county commission or city council. Functional consolidation requires approval by the elected officials of the component governments on an on-going basis. A basic drawback to functional consolidation is that it does not eliminate overhead administrative costs in the same way as consolidated government. Government structures still remain fragmented. Multiple records and cost accounts mean that taxpayers will not receive the same level of savings from functional con- 
solidation as compared to fully consolidated government (University of Georgia, 2007).

\subsection{The Process of Consolidation}

By its nature, the consolidation process is slow and time consuming. Whether the impetus for consolidation is derived from a mass movement or led by highly effective political leaders that rally the political elite and articulate a message that resonates in the community, the procedural and legal hurdles to overcome are daunting, complex, and protracted. In Georgia, a consolidation effort can take one of two routes.

Once the idea has gained acceptability in the corridors of power, one path is for the City and County Commissions to agree to pass a constitutional amendment authorizing the Georgia General Assembly to create a charter commission to conduct in-depth studies on the scope, modalities, and time frame for the consolidation. The functions of the commission include drafting a charter for a consolidated government. The alternative consolidating process is the referendum, whereby citizens of the jurisdictions decide the issue.

In the case of the consolidation of Athens and Clarke County, the first unification referendum was held on March 12, 1969. This vote which required the passage of two separate counts failed, because while the measure passed by $59.8 \%$ in the city, it failed in the county with only $29.3 \%$ support. The second attempt in 1972 produced virtually the same results: $52 \%$ approval in the city and $42 \%$ support in the county. A third vote in 1982 produced similar outcome: $55 \%$ approved in the city of Athens, while the county residents rejected the move with $45 \%$ support rate. It was at the fourth attempt, in August 1990, that unification finally materialized when the City of Athens residents voted 58\% in support of consolidation, while Clarke County citizens also voted 59\% in support of unification (Smith, 1997).

\subsection{Potential Barriers to Consolidation}

While promises of consolidating county and city governments for economic and efficiency reasons have become popular for reformist politicians of late, empirical evidence points to a dismal $80 \%$ failure rates at consolidation attempts nationwide (Leland \& Thurmaier, 2010: p. 1). Factors that account for the dreary success rate of consolidation efforts include the fact that there is little evidence to convince voters that consolidated governments are more efficient than separate city and county governments.

The other structural reason why consolidation efforts often fail to materialize is the issue of "fair" representation based on race or class cleavages. For instance: Do a county and a municipality both with $80 \%$ white population stand a better chance of consolidation than another county and city with a different demographic make-up? How about a scenario where a city has a majority black population seeking to consolidate with a county with majority white population, or vice versa? Since majority racial or ethnic population invariably translate to political power, what are the chances that a city with majority black population would vote to create a consolidated government with a county whose population is majority white, a development that would guarantee the loss of political power for black elected officials?

Closely tied to racial/ethnic politics is class. If a county population is more affluent and well-to-do compared to the average income/class status of the center-city population, any merger proposals could be viewed from the point of view of job losses in the inner city or tax increases for the urban population.

An example of this racial and structural divide played itself out in the run up to the just consolidated Bibb County and the City of Macon of Central Georgia. While Bibb County is made up of 52.5\% black and 44.1\% white, City of Macon has $68 \%$ black population, contrasted with only $29 \%$ white. Before the consolidation proposals, the City of Macon's fifteen-member City Council had eight black commissioners and seven white commissioners. The Bibb County Commission also had three black commissioners and two white commissioners. The Consolidation Proposal, which was approved by Georgia State General Assembly, created a nine-member County Commission, with 5 seats going for blacks and 4 seats set aside for the white population.

The decision to replace the City of Macon's fifteen-member Council to nine for a city the size of Macon could be deemed not only prudent but economical. However, looking at the composition of the consolidated government, although still maintaining a thin majority in the union government, African Americans go from holding 11 elected office to 5 in the same geographic area after consolidation. It was therefore predictable that black politicians who feared losing their seats resisted consolidation (Stucka, 2012).

According to a Macon Telegraph survey of Macon City Council members and Bibb County Commissioners in July 2011, there was a strong racial divide on consolidation. Elaine Lucas—a black council woman — feared that 
the consolidation would dilute the voting strength of blacks. She thought the new district maps would give white Republicans an advantage. The white population, on the other hand, fretted that merging the city and county jurisdictions would mean county tax payers end up "pulling the slack" of the city, meaning tax increases to support the city. At the same time, city black residents feared property tax increase and job cuts that would invariably start from the bottom (Stucka, 2012).

While Leland and Johnson conclude that more empirical studies are needed to determine whether or not increased minority representation on governing bodies will result in public policies more favorable to the minority community, they admit that results of other studies point to a certainly positive relationship between elected minorities and municipal employment of minorities (2004).

\subsection{Albany-Dougherty}

Dougherty County, whose administrative seat and largest city is Albany, was created out of Baker County by the Georgia Legislature in 1853, as Georgia's 103rd county. According to the U.S Census Bureau, the county has a total area of 335 square miles and a total population of 94,565 people. The racial makeup of the county is $37.80 \%$ white and $60.13 \%$ Black or African American. Hispanic or Latino of any race comprises $1.34 \%$ of the population. Apart from the main city of Albany, Dougherty County comprises unincorporated communities of Acree, Pecan City, Pretoria, Putney, and Radium Springs.

The City of Albany was incorporated by an Act of the General Assembly of Georgia on December 27, 1838, and has operated under the commission-manager form of government since January 14, 1924. Located in southwest Georgia, Albany is the county seat of Dougherty County (New Georgia Encyclopedia, 2014). The seven-member Commission consists of a Mayor elected at-large and six Commissioners elected from single-member districts. The Commission also appoints members to various boards, authorities, and commissions. The Commission also appoints the City Manager, City Clerk, City Attorney, and Municipal Court Judge. The City Manager, the city's chief administrative officer, is responsible for enforcing laws and ordinances and implementing policies passed by the Commission. The City Manager appoints department heads to assist with these responsibilities.

Currently ranked Georgia's tenth (10th) most populous city, Albany has a population of 77,434 (2012 estimate). Albany moves up two notches (ranked 8th) when it comes to Georgia's fifteen Metropolitan Statistical Areas, where, together with Baker, Dougherty, Lee, Terrell, and Worth counties showcases a population of 157, 308 (United States Census Bureau, 2012). Albany is considered the industrial, business, retail, education, cultural activities, healthcare, and media hub for a robust growing region that includes parts of Florida and Alabama, as well as Georgia. As one of the most economically active areas in Georgia, Albany supports over 118 manufacturing plants. Albany's top ten largest employers include Phoebe Putney Hospital, Miller Brewing SAB, CallTech Communications, LLC, Albany State University, Coats \& Clark, and Masterfoods USA.

The City of Albany is now, more than ever, positioning itself to be the regional leader. At the commissioning of Albany Riverquarium in 2004, Albany's mayor, Dr Adams called for the upgrade of Albany Airport, among other initiatives, to make Albany the economic, cultural, educational, and sporting center for the entire southwest Georgia (Bensonhaver, 2004).

\subsection{Early Attempts of Unification}

The history of the City of Albany and Dougherty County unification goes as far back as 1954 when the first effort at consolidating the governments of the City and the County occurred (National Association of Counties, 2014). The efforts were discontinued for lack of political will after another consolidation attempt in 1956 . The issue was revisited in 1972 with the signing of the 1972 Delineation of Services Agreement between the City and the County. This enabled the City and County to consolidate departments such as Planning, Voter Registration, and Tax Office.

There was also the 1999 Service Delivery Strategy move by the City and County and submitted to the Department of Community Affairs. This agreement was in compliance with Georgia's General Assembly 1997 directive (House Bill 489) which set a deadline of July 1, 1999 for each county, and cities within the county, to adopt a Service Delivery Strategy. This blueprint outlined cooperative agreements between the City and County for delivery of services for the following:

- Airport 
- Animal Control

- Occupation Tax, Assessment and License Collection

- Facility Management

- Emergency Management Services

- Procurement

- Traffic Engineering

- Jail Services

- Albany Dougherty Drug Unit

- Keep Albany Beautiful Commission

- Solid Waste Fill

- Economic Development Commission

- Department of Information Technology

- Fire Protection

- Water Service

- Sewer Service

- Water and Sewer Rates

- Process for the Provision of Extraterritorial Water and Sewer Services

- Planning and Development Services Department

- Storm Drainage

- Tax Collections

- Recreation (Still in Progress)

- Transportation

This, essentially, leaves the City and County with only four departments in which cooperative agreements are not currently in place, in addition to the elected officials and other top appointed officers in the City and County. The four remaining departments in which cooperative agreements are not in effect are Personnel, Police, Finances, and Public Works.

The most recent plea for greater unification was the result of an initiative by One Albany, an interracial group of twenty-four community leaders committed to the enhancement of economic and social progress for citizens of the region. One Albany in 2002 used its platform to appeal to leaders of the City and County to explore the possibility of consolidating Albany and Dougherty County governmental functions.

\subsection{Current Efforts at Unification}

A joint resolution to establish an Albany-Dougherty County Governmental Study Commission was approved by the two governments within a period of two weeks in 2003. The Board of Commissioners of Dougherty County, Georgia voted on the issue on April 7, 2003, while the Board of Commissioners of the City of Albany approved a similar resolution on April 22, 2003.

The Albany-Dougherty Governmental Study Commission employed several methodologies to complete its assignment in a timely manner. In addition to requesting and obtaining historical documents from City and County administrators, Commission members also made field visits and presentations with three of the aforementioned consolidated City-County governments in Georgia (Columbus/Muscogee County; Athens/Clarke County; and Augusta/Richmond County). The Commission, in addition, employed the services of Del Delaper and Associates, a consulting firm to facilitate in-depth interviews and work sessions with designated city and county governmental department personnel to identify perceived advantages and disadvantages of consolidation and other related externalities. Six public hearings were also conducted between April 5 and 8, 2004 in locations as diverse and widespread as the Government Center, Putney Community Center, and Monroe Comprehensive High School. Other public hearing locations were Robert Cross Magnet School, Deerfield Windsor School, and Mock Road Elementary School, where concerned citizens were provided the opportunity to voice their hopes and reservations on consolidation.

\subsection{Governmental Study-Final Report}

The final report on the possible consolidation of Albany City and Dougherty County was submitted to the Study Commission on April 23, 2004 by Del Delaper and Associates, the consulting firm. The Study Commission now 
has to refer the issue to the City and County governing bodies for consideration. The final stage will be for the City-County Commissions to refer the consolidation issue to citizens of the two jurisdictions for ratification via a referendum.

So, where does Albany-Dougherty stand in terms of possible success in their consolidation effort? Since local leaders ultimately look to the voters, the vetting of any consolidation effort falls upon the shoulders on the citizens of Dougherty County and the City of Albany. We turn to our results from an exit poll to see how any such effort might fare.

\section{Data and Methodology}

These data were collected on Election Day, November 13th 2012 at five precincts in Dougherty County, Georgia. Three of the precincts were randomly selected, while the remaining two precincts were selected for their racial and party affiliation composition. As a predominantly African American and Democrat county, it was necessary to select two precincts that typically have white and Republican voters. Students enrolled in various political sciences classes at Albany State University manned the exit polling stations from open-to-close (7:00 a.m.-7:00 p.m.). A skip count of 2 was used at all precincts. All potential respondents were approached and verbally asked to participate in the poll. If agreeable, the respondent was consented, and the survey initiated. This research study was approved by the Albany State University's Institutional Review Board.

The instrument used for this study was one of two survey forms interspersed in alternating fashion. There were one-hundred-ninety-four (194) consolidation surveys collected. A formal response rate was not calculated. The survey contained nine (9) consolidation questions, as well as sociodemographic and other predictor questions. The nine consolidation questions are:

For each of the services, please indicate if you would like it to remain independent or be consolidated.

Question 1: Albany Police and Dougherty County Police

Question 2: City and County parks

Question 3: City and County tax departments

Question 4: City and County purchasing departments

Question 5: Albany Mayor and County

Question 6: Commission Chairman

Question 7: Do you live within the Albany City limits or in the County?

Question 8: Do you support or oppose the consolidation of Albany and Dougherty into one unified government?

Question 9: How would you like the decision about a possible merger of the City of Albany and Dougherty County be made?

The demographic questions are:

Which category best describes your household income?

LT $\$ 15,000$

$\$ 15,001$ to $\$ 25,000$

$\$ 25,001$ to $\$ 35,000$

$\$ 35,001$ to $\$ 45,000$

$\$ 45,001$ to $\$ 55,000$

$\$ 55,001$ to $\$ 65,000$

$\$ 65,001$ or more

What is your race?

Black

White

Other

Do you identify as:

Male

Female

Do you live within the Albany city limits or in the county?

Inside City

In County 
Age was asked as "What year were you born?" and then calculated and transformed into ordinal categories:

$18-25$

$26-45$

$46-65$

$65+$

\section{Findings-Exit Poll}

In our survey, we asked respondents to indicate if they preferred that several key governmental functions remain independent, or if they should be combined. Table 2 shows the responses to these questions in descending order of magnitude for remaining independent.

As the table indicates, a vast majority of citizens prefer that most of City-County services remain independent. In fact, approximately two-thirds (66.40\%) prefer to keep the City Mayor and County Commission Chairman independent, while over sixty percent respond that the tax and police departments $(62.80 \%, 62.10 \%$, respectively) should also be independent. About one-half (50.70\%) would keep parks independent.

We also asked three questions measuring voters' support levels of consolidation including a general support question, a question concerning by whom the consolidation decision should be made, and a question of respondent residency; city or unincorporated county. Table 3 presents the overall support or opposition findings.

Interestingly, although a majority of respondents want specific services provided by county and city governments to remain independent (see Table 1) a large majority of the same respondents strongly support or support $(61.80 \%)$ consolidation of the two entities. Clearly, when it comes to the general notion of efficiency and cost effectiveness, the voters in Dougherty County prefer consolidation. However, when it comes to the specifics, residents want to protect their important services. Thus, they want to maintain control of vital departments like tax and police, but not as much with parks. On a methodological note, it is also interesting that the general Support/Oppose question came after the specific services on the survey. Thus, respondents were largely aware of their inconsistent responses of wanting certain services to remain independent, while supporting consolidation, in general.

We also asked voters how they would like to see the consolidation issue resolved (see Table 4).

Table 2. Preferences for independence.

\begin{tabular}{ccc}
\hline Should Albany and Dougherty County: & Remain Independent & Be Combined \\
\hline Mayor and Commission Chairman & $66.40 \%$ & $33.60 \%$ \\
Tax Departments & $62.80 \%$ & $37.20 \%$ \\
Police & $62.10 \%$ & $37.90 \%$ \\
Purchasing Departments & $60.40 \%$ & $39.60 \%$ \\
Parks & $50.70 \%$ & $49.30 \%$ \\
\hline
\end{tabular}

Table 3. Support or oppose consolidation.

\begin{tabular}{ccc}
\hline Do you support or oppose the consolidation of Albany and Dougherty into one unified government? & Valid Percent \\
\hline Strongly Support & $15.00 \%$ \\
Support & Oppose & $46.80 \%$ \\
& Strongly Oppose & $25.40 \%$ \\
\hline
\end{tabular}

Table 4. Consolidation process preference.

\begin{tabular}{cc}
\hline How would you like the decision about a possible merger of the City of Albany and Dougherty County be made? & Valid Percent \\
\hline City/County Voters (Referendum) & $64.70 \%$ \\
City/County Commissions & $27.60 \%$ \\
State Legislative Action & $7.70 \%$ \\
\hline
\end{tabular}


Overwhelmingly (64.70\%), citizens want to see the issue put on the ballot for a referendum. Approximately one-quarter (27.60\%) want the City/County Commissions to take action, and less than one-in-ten (7.70\%) want the State Legislative mandate.

In order to explore voter attitudes toward consolidation in greater detail, we ran a series of bivariate cross tabulations. We used the demographic variables of age, income, race, gender, and residency status to try and explain the variation we found in the public service variables presented above. Table 5 displays the frequency distributions percentages for predictor variables used in our analysis.

Table 6 displays the Chi-Square probabilities for each of the listed demographic variables calculated for each of the City-County services.

Table 5. Demographics.

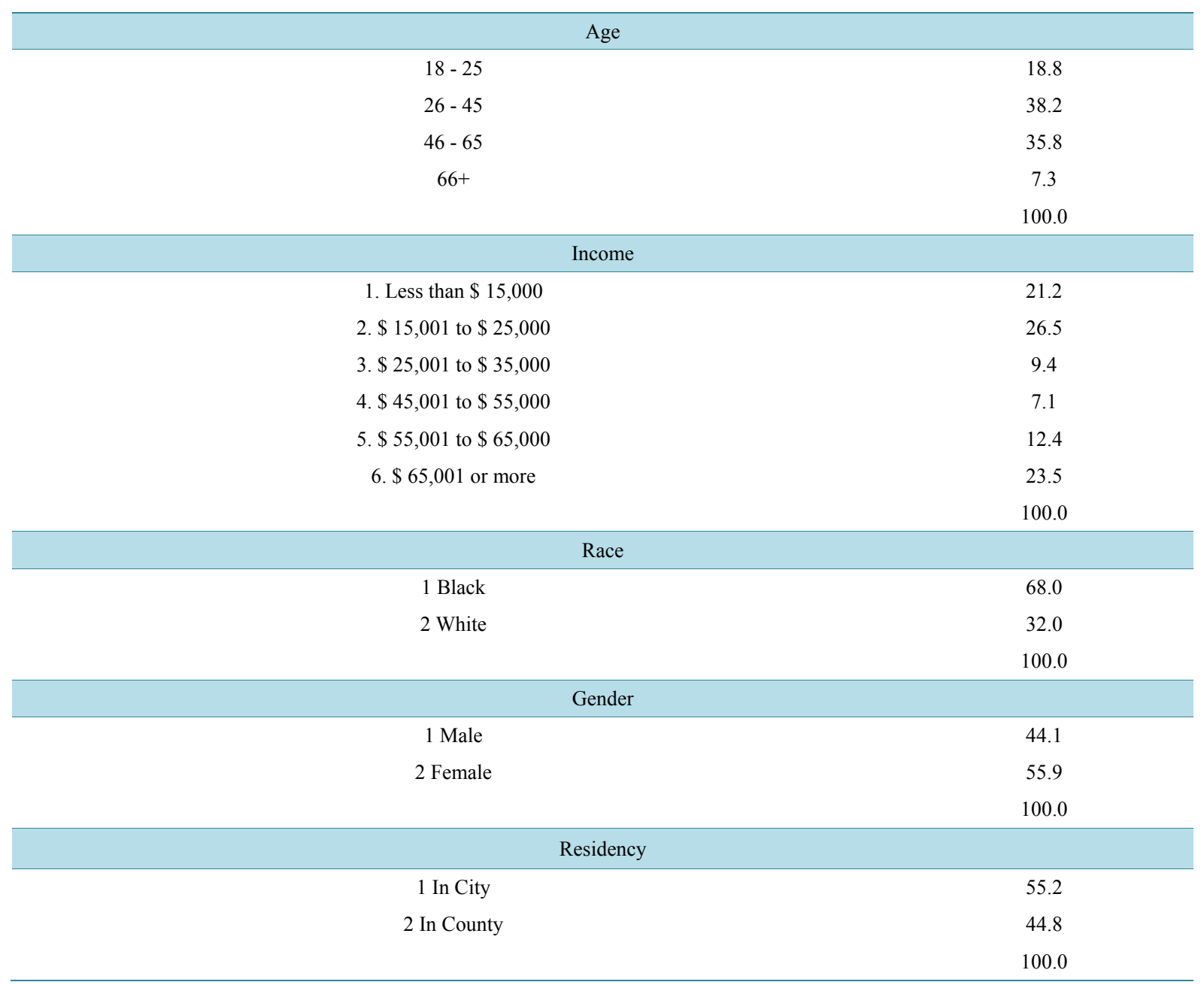

Table 6. Chi-square probabilities for demographic variables.

\begin{tabular}{cccccc}
\hline & Police & Parks & Tax & Purchasing & Mayor \\
\hline Age & 0.510 & 0.456 & 0.603 & 0.592 & 0.691 \\
Income & 0.730 & 0.503 & 0.459 & 0.210 & 0.336 \\
Race & 0.084 & $0.045^{*}$ & 0.145 & 0.520 & 0.233 \\
Gender & $0.003^{*}$ & $0.000^{*}$ & $0.002^{*}$ & $0.028^{*}$ & 0.241 \\
Residency & 0.093 & 0.191 & 0.151 & 0.437 & 0.320 \\
\hline
\end{tabular}

*statistically significant at the 0.05 level. 
For four (4) of the public services - police, parks, tax, and purchasing departments, gender is the only variable that is statistically significant at the 0.05 level. For parks, approximately two-thirds (64.90\%) of women polled want to see county and city parks remain independent, while only one-third $(34.40 \%)$ of men share this view. A similar situation exists with race, where approximately two-thirds $(63.00 \%)$ of white respondents want to see parks independent, and less than one-half $(45.90 \%)$ of black respondents agree. In terms of police services, seven-out-of-ten $(73.20 \%)$ women and one-half $(50.00 \%)$ of men want the Albany and Dougherty police to remain independent. Similar differences exist between women and men for the remaining services with women $/ \mathrm{men}$ preferring independence for tax $(73.80 \% / 49.20 \%)$, purchasing $(68.40 \% / 50.80 \%)$, and the city mayor and county commission chairman $(70.10 \% / 63.20 \%)$. Thus, for these particular public services, women tend to favor independence to a greater degree than men.

We also asked voters if, in general, they support or oppose consolidation of City-County services. In contrast to each of the individual public services, the respondents support the general idea of consolidated government. Our analyses show that age, income, race, and place of residency (city or county) all influence consolidation preferences. The only variable that does not have a statistically significant relationship with support for consolidation is gender.

We find a statistically significant relationship between support for consolidation and the age of the respondent with younger voters (ages $18-45)$ more likely to support than are their older (45+) counterparts. Table 7 shows the variables and their Chi-Square probabilities.

Income appears to have a nonlinear relationship with attitude toward consolidation with the lowest income group being both the strongest supporters and opposers of consolidation. The highest income respondents are more likely to somewhat support than to oppose, while those with moderate incomes walk the fence on the issue. We also find that black voters are far more likely to support consolidation than are white voters. Interestingly, when controlling for residency (city or county) we find that black voters in the county are far more likely to support consolidation than white voters. In the city, there is no difference between the races and their support.

Finally, we asked voters how they would like to see the consolidation issue resolved - through voter referendum, city/county commission action, or action by the state legislature. We see another nonlinear relationship between age and preferences on how a consolidation decision should be made. Younger (18 - 25) voters and older $(46+)$ voters prefer referendum, while those aged 26 to 45 prefer that the city and county commissions make the decision.

Table 8 shows the variables and their Chi-Square probabilities.

Our analyses have provided greater insight into voter attitudes concerning consolidation of Dougherty County and the City of Albany. We have learned that there is support for the broad notion of consolidation, and that age,

Table 7. General support or opposition to consolidation.

\begin{tabular}{cc}
\hline & Chi-Square Probabilities \\
\hline Age & $0.023^{*}$ \\
Income & $0.022^{*}$ \\
Race & $0.030^{*}$ \\
Gender & 0.471 \\
Residency & $0.007^{*}$ \\
\hline
\end{tabular}

*statistically significant at the 0.05 level.

Table 8. How should the consolidation decision be made?

\begin{tabular}{cc}
\hline & Chi-Square Probabilities \\
\hline Age & $0.009^{*}$ \\
Income & 0.198 \\
Race & 0.063 \\
Gender & 0.826 \\
Residency & 0.780 \\
\hline
\end{tabular}

\footnotetext{
"statistically significant at the 0.05 level.
} 
income, and race affect voters' attitudes, but that when it comes to specific public services support wanes. To a large extent, women prefer to keep these services independent.

\section{Discussion}

As Hardy details, there are several pros and cons of consolidated government. Among the benefits cited are greater efficiency and reducing the duplication of services, and economies of scale. On the negative side of the ledger, reduction in services or possible service cost increase, decision making difficulties, and loss of the sense of community, are all potential pitfalls to unification (Hardy, 2012).

The data collected tell an interesting story about consolidation in Albany-Dougherty County, Georgia, and how these pros and cons are balanced out in citizen calculations and considerations. Although a majority of voters prefer to keep important services independent, there is strong support for consolidated government. This apparent cognitive dissonance is most likely a result of wanting the obvious benefits of a more efficient and effective local government, but also a desire to keep control of important services in the hands of the most proximal government. We see this manifestation in our data where the support is greatest for combining parks, and least for Mayor and Commission Chairman.

There is little doubt that economic factors are an important consideration when government officials consider consolidation. However, it is possible that these same economic considerations are less important to the citizens. It is our proposition that the loss of a sense of community cited by Hardy (2012) and related feelings of localism is the driving force behind the resistance to consolidated government in Albany-Dougherty.

As Gerber \& Gibson (2009) point out, "Despite the promise of enhancing economic efficiency...local actors must give up public authority to achieve regional coordination (p. 635). It is this regional view that causes resistance at the local level. Many citizens do not want regional benefits at the cost of local autonomy. The struggle for autonomous authority and control of local policy making is a powerful counterbalance to the economic efficiencies brought by consolidation.

Furthermore, Tyson (2012) posits that multiple governments result in a fragmented system where "different metropolitan municipalities take on identities that reflect disparate levels of market value, social worth, political power, and cultural meaning (p. 299). Regionalism speaks to the antithesis of this fragmentation, and also to the end of the disparate values, power and culture.

Although seemingly independent streams, at times, economic and cultural forces often collide in forming citizen preferences. As Friedman (2008) writes, "municipalities that provide social services to the needy residents may attract needy people from nearby municipalities that have less generous policies (p. 2)". Within the context of Albany-Dougherty Georgia, the city provision of social services to the needy creates an economic disincentive for county residents to support consolidation, as well as building a cultural stigma of Albany as the center for the urban poor.

As Tyson (2012) also notes, the ability of citizen to form voluntary and mutual associations with like-minded neighbors is a fundamental component of our shared vision of American democracy. "This dynamic of localism has significant cultural roots and reflects the legacy of civic republicanism and its ties to democratic citizenship, participation, and territory (Tyson, p. 328)".

Municipalities demarcate first class citizenship from subordinate tiers and add "stigma to residence and place, signaling to the market those areas for investment and isolation (Tyson, 2012, p. 330)". We find this theory having explanatory efficacy when applied to the disparities between the urban Albany and suburban Dougherty citizens. In addition, that that the market recognizes isolation is only part of the detrimental effects of place stigmatization. The potential cultural biases have their own negative impacts such as citizen's perception of self worth, political opportunity and efficacy, and community morale, to name a short list.

We are also mindful of Collins' (2004) work that supports the notion that noneconomic factors potentially play a major role in citizen preferences towards regionalism. In his study, he finds that personal characteristics are poor predictor of support/opposition to regionalism (Collins, 2004: p. 42) and hypothesizes that attitude and beliefs are formed within a broader context that incorporates "basic political and social value preferences (p. 43)."

\section{Conclusion}

In this paper we have looked at consolidation in Georgia, and at Albany, specifically. We see that although sev- 
eral large municipalities have taken the consolidation path in Georgia, it is a path that Albany will not likely follow in the near future.

We mention early on the important consolidation cleavages created by race and class. Certainly AlbanyDougherty shares this climate with Macon-Bibb and our data reflect this. In Albany-Dougherty, our data demonstrate the important role that race and class play in forming attitudes towards consolidation. Although black voters are more likely than their white counterparts to support the general concept of consolidation, there are no statistically significant differences when it comes to specific services. Blacks and whites prefer important services to be left independent. In terms of class structure, low income voters have mixed preferences, while higher income voters tend to support consolidation. It is the middle income group, the ones that can bring the consolidation movement to fruition, which is conflicted. Their fence straddling on the issue is a direct manifestation of their internal conflict over wanting efficient government, but also wanting to maintain control over their local political and governmental processes.

Albany, in this way, is similar to many municipalities across the country facing stiff voter resistance to consolidation. Interestingly, the cries for more accountable, efficient, and effective government do not fall on deaf ears. The consolidation effort has been active since the 1950s and is seen as a way to foster greater efficiency in the delivery of services. Indeed, partial consolidation already exists, with several services shared by city and county. The difficulty, then, comes not in a resistance to better government; rather, it is the structural barrier of race, class and place. Although these barriers exist elsewhere, if anything, they are amplified in Southwest Georgia.

Thus, if it comes down to choosing between good, efficient, government services and the (perceived) control of, and access to, that government, the latter is the motivating force. No one wants an inefficient or ineffective government, but when it comes to consolidation, the efficiency and effectiveness criteria take a back seat to the sociopolitical forces at work. In Albany, these forces are race and power, and the perception that African Americans control Albany and whites control Dougherty County is a tremendous barrier to hurdle.

\section{References}

Bensonhaver, A. (2004) Flint Riverquarium Makes Public Debut. Albany: Herald.

Brierly, A. B. (2004). Annexation as a Form of Consolidation: An Analysis of Central Core City Boundary Expansion in the United States during the Twentieth Century. In J. B. Carr, \& R. C. Feiock (Eds.), City-County Consolidation and Its Alternatives: Reshaping the Local Government Landscape (pp. 55-86). New York: M.E Sharpe.

Carr, J. B. (2004). Perspectives on City-County Consolidation and Its Alternatives. In J. B. Carr, \& R. C. Feiock (Eds.), City-County Consolidation and Its Alternatives: Reshaping the Local Government Landscape (pp. 3-38). New York: M.E Sharpe.

Collins, J. A. (2004). Attitudes towards Regionalism in a Rapid Growth Suburb. The Annals of Regional Science, 9, 32-43.

Feiock, R. C. (2005). Do Consolidation Entrepreneurs Make a Deal with the Devil? In J. B. Carr, \& R. C. Feiock (Eds.), City-County Consolidation and Its Alternatives: Reshaping the Local Government Landscape (pp. 39-52). New York: M.E Sharpe.

Fleischmann, A., \& Pierannunzi, C. (2000). Georgia's Constitution and Government (6th ed.). Athens, GA University of Georgia Press.

Friedman, E. (2008). Do Small Governments Make Bad Neighbors. American Law \& Economics Association Annual Meeting, 2008, 98. http://law.bepress.com/cgi/viewcontent.cgi?article=2544\&context=alea

Georgia House of Representatives (1998). HB 489-Local Government Service Delivery Strategy Agreement. http://www.legis.ga.gov/Legislation/Archives/19971998/leg/fulltext/hb489.htm\#status

Gerber, E. R., \& Gibson, C. C. (2009). Balancing Regionalism and Localism: How Institutions and Incentives Shape American Transportation Policy. American Journal of Political Science, 53, 633-648.

http://dx.doi.org/10.1111/j.1540-5907.2009.00391.x

Hardy, P. (2012). The Pros and Cons of Consolidated Government. Municipal Technical Advisory Service. Knoxville, TN: The University of Tennessee.

Johnson, L. S. (2004). Revolutionary Local Constitutional Change. In J. B. Carr, \& R. C. Feiock (Eds.), City-County Consolidation and Its Alternatives: Reshaping the Local Government Landscape (pp. 155-182). New York: M.E Sharpe.

Johnson, L. S., \& Carr, J. B. (2004). Making the Case for (and against) City-County Consolidation: A Qualitative Comparative Analysis. In J. B. Carr, \& R. C. Feiock (Eds.), City-County Consolidation and Its Alternatives: Reshaping the Local Government Landscape (pp. 246-290). New York: M.E Sharpe. 
Katz, B. (2000). Editor's Overview. In B. Katz (Ed.), Reflections on Regionalism (p 1-7). Washington DC: Brookings Institution Press.

Koven, S., \& Lyons, T. (2010). Economic Development: Strategies for State and Local Practice (2nd ed.). Washington DC: International City/County Management Association.

Leland, S. M., \& Johnson, G. A. (2004). Consolidation as a Local Government Reform: Why City-County Consolidation Is an Enduring Issue. In J. B. Carr, \& R. C. Feiock (Eds.), City-County Consolidation and Its Alternatives: Reshaping the Local Government Landscape (pp. 25-38). New York: M.E Sharpe.

Leland, S. M., \& Thurmaier, K. (2010). Case Studies in City-County Consolidation: Promises Made, Promises Kept? Washington DC: Georgetown University Press.

National Association of Counties (2014). City-County Consolidation Proposals. www.naco.org/Counties/learn/Documents/City\%20County\%20Consolidations.01.01.2011.pdf

New Georgia Encyclopedia (2014). Counties, Cities, and Neighborhoods: Albany. http://www.georgiaencyclopedia.org/articles/counties-cities-neighborhoods/albany

O’Toole, R. (2005). Ideological Train Wreck Disguised as "Research Study". Produced by Light Rail Now! Publication Team.

Savitch, H. V., \& Vogel, R. K. (2000). Introduction: Paths to New Regionalism. State \& Local Government Review, 32, 158168. http://dx.doi.org/10.1177/0160323x0003200301

Smith, D. E. (1997). A History of the Unification of the Athens-Clarke County Government. http://athensclarkecounty.com/113/Unification-of-Athens-Clarke-County

Stucka, M. (2012). Analysis: Consolidation Map Splits Bibb into White Republican, Black Democratic District. http://www.macon.com/2012/03/25/1962387/analysis-consolidation-map-splits.html

Tyson, C. J. (2012). Localism and Involuntary Annexation: Reconsidering Approaches to New Regionalism. Tulane Law Review, 87, 297.

United States Census Bureau (2012). Table CBSA-EST2012-02 2012. www.census.gov/popest/data/metro/totals/2012/tables/CBSA-EST2012-02.csv

University of Georgia, Carl Vinson Institute of Government (2007). An Initial Assessment of Consolidation Feasibility for Fayetteville and Cumberland County North Carolina.

https://www.co.cumberland.nc.us/public info/news releases/2007/August/Initial Assessment of Consolidation Feasibili ty $08292007 . \mathrm{pdf}$ 